\title{
Angles
}

New Perspectives on the Anglophone World

$8 \mid 2019$

Neoliberalism in the Anglophone World

\section{Reclaiming Our Universities: A Manifesto to Dismantle the UK HE Sector Neoliberal Agenda}

\section{Marian Mayer and Sue Eccles}

\section{(2) OpenEdition}

1 Journals

\section{Electronic version}

URL: https://journals.openedition.org/angles/653

DOI: $10.4000 /$ angles.653

ISSN: 2274-2042

\section{Publisher}

Société des Anglicistes de l'Enseignement Supérieur

\section{Electronic reference}

Marian Mayer and Sue Eccles, "Reclaiming Our Universities: A Manifesto to Dismantle the UK HE Sector Neoliberal Agenda", Angles [Online], 8 | 2019, Online since 01 April 2019, connection on 06 June 2022. URL: http://journals.openedition.org/angles/653 ; DOI: https://doi.org/10.4000/angles.653

This text was automatically generated on 6 June 2022.

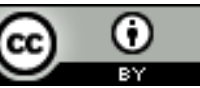

Angles est mise à disposition selon les termes de la Licence Creative Commons Attribution 4.0 International. 


\title{
Reclaiming Our Universities: A Manifesto to Dismantle the UK HE Sector Neoliberal Agenda
}

\author{
Marian Mayer and Sue Eccles
}

\section{Background and Context}

1 This article began as a response to the introduction of the Higher Education and Research Act (HERA) (2017), which in effect opens the door to privatised, deregulated Higher Education (HE) in the UK. The Act allows private for-profit companies, from their inception, to use the university title (previous legislation required a waiting period of four years), to award degrees, and to charge unregulated fees; they will not be required to establish or fund student unions. Academic freedom, as understood by publicly-funded HE, will not be protected and for-profit private universities will be able to close unprofitable courses with no liabilities to either staff or students. The neoliberal project is writ large (Harvey 2007, Hall 1978, 2011). Morgan (2017b) described the bill as "the most significant sector legislation in 25 years to further a market approach in England". It is also important to note that as Morley (2016) observed, privatised Higher Education is antithetical to critical thinking, a cornerstone of the pursuit and creation of evidenced-based knowledge. The recent announcement of a new 'civic' university in Milton Keynes, MK:U, positioned to focus on digital skills and employability, will have a "business-facing approach" according to Ryals (2018), currently the Pro Vice-Chancellor for Education at Cranfield University, and appointed as Programme Director for MK:U. Ryals (2018) posits the business model for MK:U, referring to 'lifelong learning':

There's a need to refresh skills every few years or so, and MK:U will be geared towards ongoing relationships with its learners and opportunities for re-joining the campus community.

2 Announcing the new university, Ryals (2018) offers no detail about the ways in which MK:U is to be funded. However, she does make reference to the possibilities for 
"business partnership" and employs the language of neoliberal ideology, e.g. "the university offering" and "a lead role for a business in design, delivery and support via placements." A new entrant, fast on the heels of the HERA 2017.

In a further example of the commodification of HE, a group of Oxford academics have launched a 'university app', which they describe as "the Uber of degree courses; for teachers, it will be the Airbnb of course hosting." In an interview with Roller (2018), the founder and director of Woolf University, Junior Research Fellow Joshua Broggi stated that:

The university will use blockchains with smart contracts to automate core administrative procedures, which can lower our overhead costs, reduce tuition fees, and secure significantly better salaries for academics.

Presciently, Morley (2016) predicted the 'uberisation' of higher education. It has been estimated that these 'blockchain' degrees will cost approximately $£ 40,000$ to complete. Validated by traditional universities, Woolf University was due to be launched at the beginning of the academic year 2018/19. Emeritus professor of educational technology at the Open University, Mike Sharples, questioned Woolf University's ability to provide a high standard of teaching, contending that whilst it will be possible to "assure that an interaction has taken place between two parties" [academic and student], it "cannot assure quality" (Roller 2018). These new entries into the HE sector purport to offer benefits; MK:U is being positioned as a 'civic' university, intended to create graduates with digital skills for the "fourth industrial revolution" (Ryals 2018), whilst Woolf University contends economic benefits for students and academics. Neither University was discussed in terms typically associated with HE, such as the creation of knowledge, academic freedom of thought and speech, or critical reflective analysis and enhanced understandings of society or the wider world.

Holmwood (2017) argued that HERA "completes a process of the privatisation of higher education in England". For academics working in the humanities and social sciences, the removal of funding for these disciplines has been keenly felt. Holmwood cites the complicity of senior university leaders as key to the privatisation of HE; his pessimism echoes that of Collini (2017: 203), who refers to the failure of academia to resist and defend against the Act describing this as a "loss of nerve" in universities; in effect an inability to defend publicly-funded HE.

\section{Fighting the Neoliberal Agenda}

6 However, one event has significantly changed the UK HE landscape and demonstrated a more recent attempt to challenge the neoliberal agenda. The recent University and College Union (UCU) industrial action, in defence of pensions for staff working in pre-92 universities began in February 2018. According to Schwarz (2018: 9)

[...] for reasons which are still not clear, the employers - the Universities UK (UUK)

- settled on what was in effect a frontal assault against the University and College

Union (UCU).

UCU members voted to strike for 14 days during February and March, and at its height 65 institutions were affected by the action (UCU March 2018). In ways that UCU activists had no reason to envision, students joined academics on picket lines and most surprisingly occupied - at one point - some 20 university buildings, including the 
London School of Economics, Liverpool University, Reading University, University College London, Southampton and Sussex University and others (Figures 1 and 2).

Figure 1. Occupation at Queen Mary University

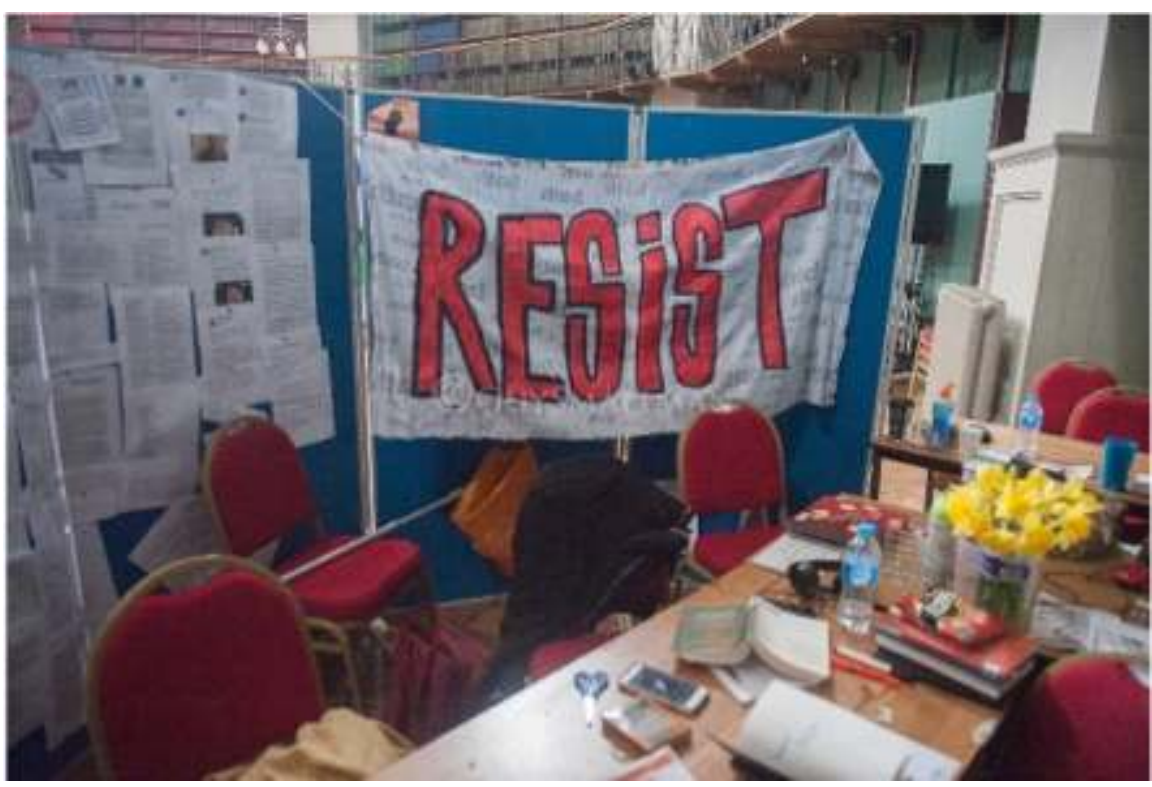

Source: Left Foot Forward, 2018.

Figure 2. Referencing Marx

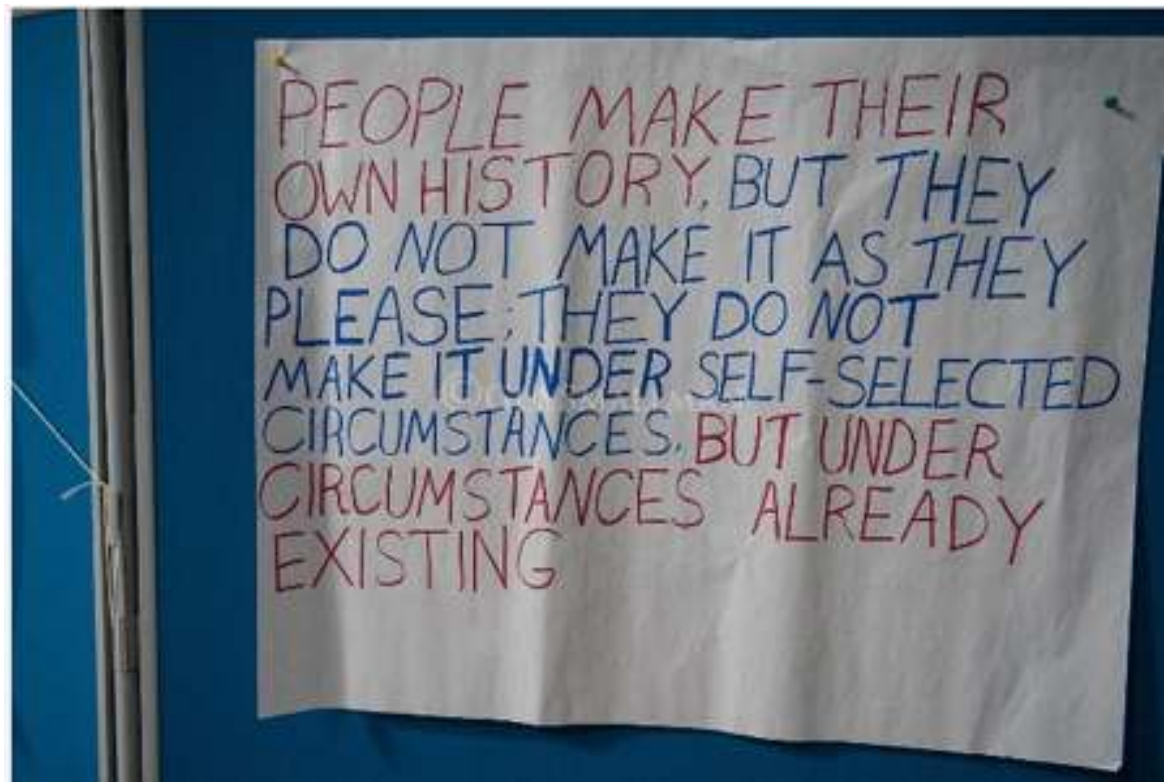

Source: Left Foot Forward, 2018 
Figure 3. Bristol University 'Student Staff Solidarity Group' occupy the Senate room

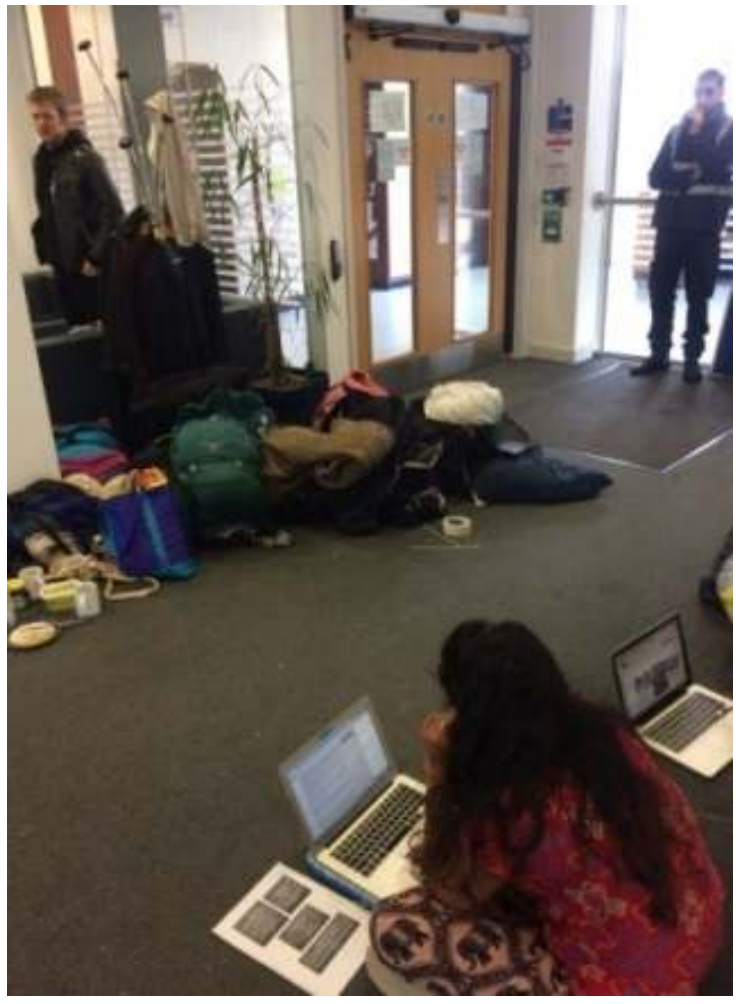

Source: The Tab, 2018.

Figure 4. Bristol University 'Student Staff Solidarity Group' occupy the Senate room

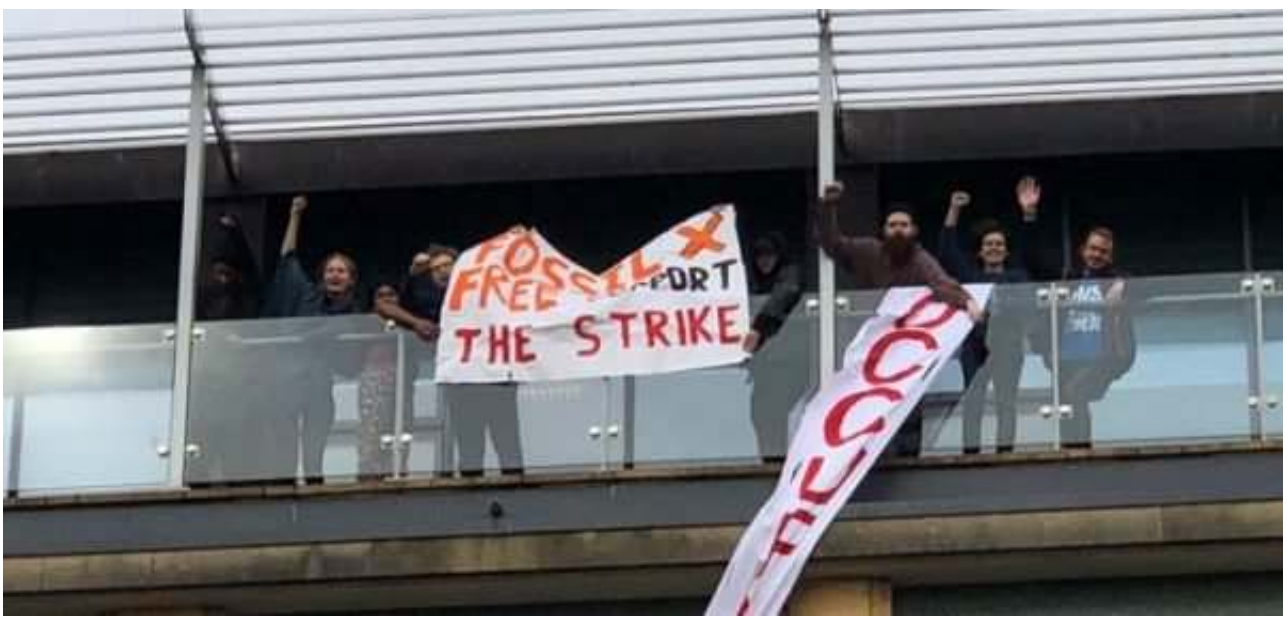

Source: The Tab, 2018 
Figure 5. Glasgow University Strike. Solidarity Occupation. March 15, 2018

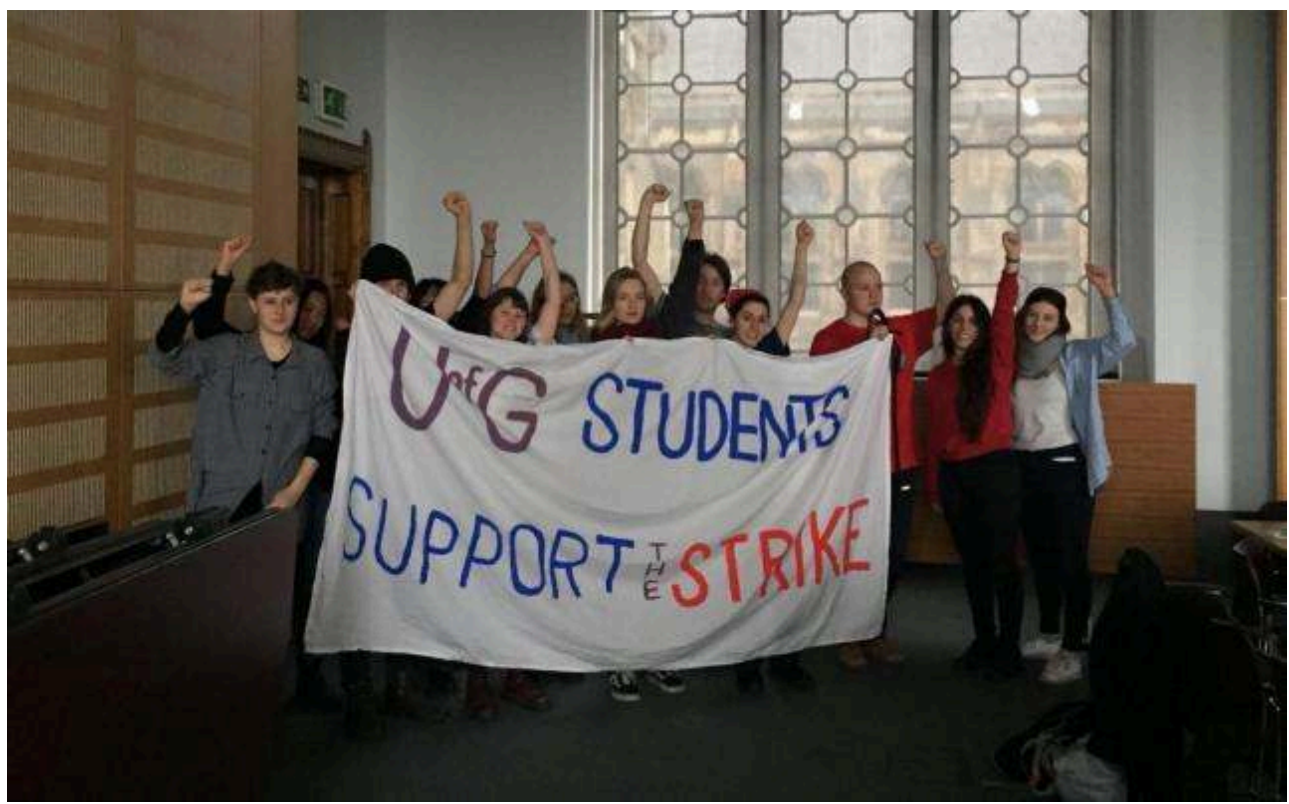

Source: Caitlin Logan, 2018. https://sourcenews.scot/occupied-glasgow-students-show-solidaritywith-striking-lecturers/

Figure 6. University of Strathclyde (Glasgow) students support the strike, March 15, 2018

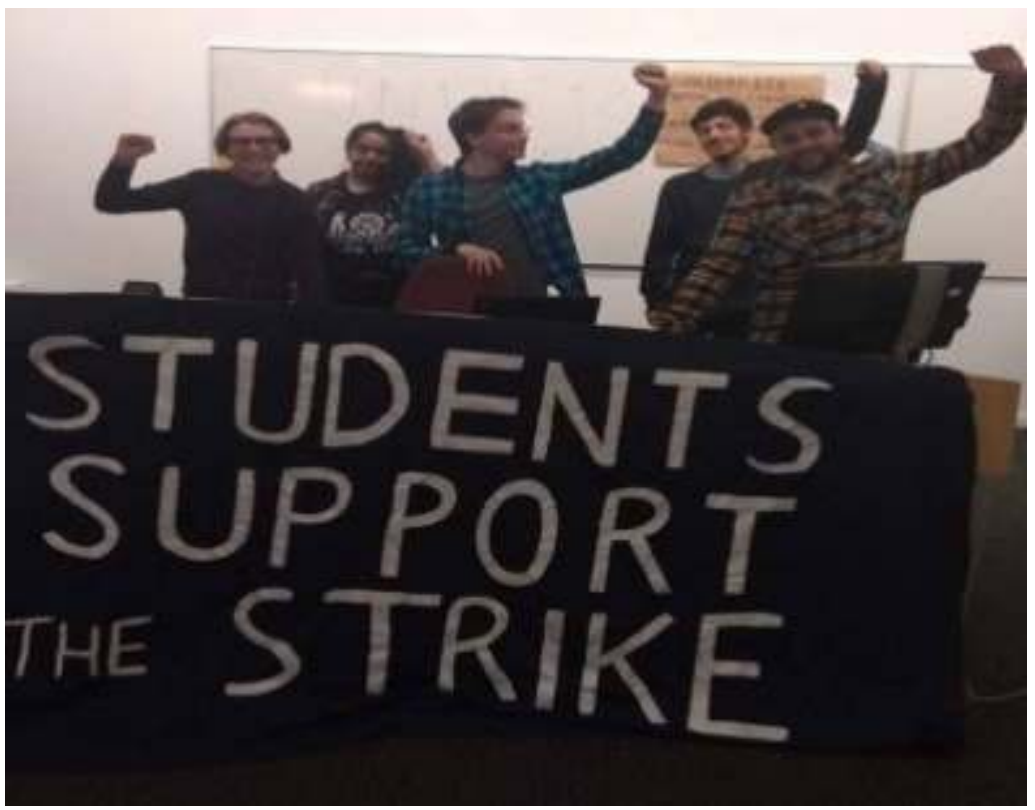

Source: https://www.facebook.com/photo/?fbid=609189756084702\&set=a. 593075004362844

8 In addition to marches through cities across the UK, Bristol University's ViceChancellor's Office was occupied (Cork 2018; Figures 3 and 4) and Glasgow University students, organised as 'Glasgow University Strike Solidarity' in support of the industrial action, occupied the Senate Room (Figures 5 and 6) issuing the following statement:

We are here in solidarity with striking members of staff and to remind our university management where their sympathies should lie. This also a show of solidarity with occupying students across the UK. (BBC 2018) 
Students and striking academics came together to defend HE as never before. According to a recent yougov poll (UCU 2018c), 61\% of HE students supported the industrial action, with $66 \%$ studying in institutions affected by the strike supporting the action. Interestingly, only $2 \%$ of those polled held academics responsible for the action, $20 \%$ responded that both staff and employers were at fault, whilst $50 \%$ blamed the employer. This response by students was in stark contrast to a widely-held, neoliberal belief that as 'consumers' of education they would express anger over the strikes. Interestingly, however, a small number of students demanded compensation from universities for breach of contract. Group claims are being encouraged by Law Firms, such as Asserson's University Group Claim's website contending that:

This is your chance to be paid fair compensation for lost teaching time, and to show that like any consumers, students won't pay something for nothing. (Asserson Law Offices 2018).

This is arguably an unintended consequence of the commodification of HE, in particular the Competition and Market Authority's (2015) consumer advice to students regarding UK legal frameworks protecting consumers' rights. It should be noted that this consumerist approach to education is not restricted to the recent industrial action; one Oxford graduate recently failed in an attempt to sue the University for failing to achieve a first-class degree arguing that they had received "negligently inadequate teaching" (Mortimer 2018).

11 Nevertheless, unprecedented numbers of staff and students protested not only on the attack on academic pensions - the marketization and commodification of HE was cited as a primary motivation for supporting the strike. Rebel Architects Faction (RAF), for example, blocked the gates of Cambridge University (Figure 7) stating that:

Architecture students fully support the strike and will not cross picket lines. Attacks on our staff are attacks on our education. Already many junior staff and students struggle to afford the basic necessities of a dignified life, suffer under an escalating mental health crisis and are exploited at every turn. Enough is enough: our futures are not for sale. 
Figure 7. RAF action at Cambridge University

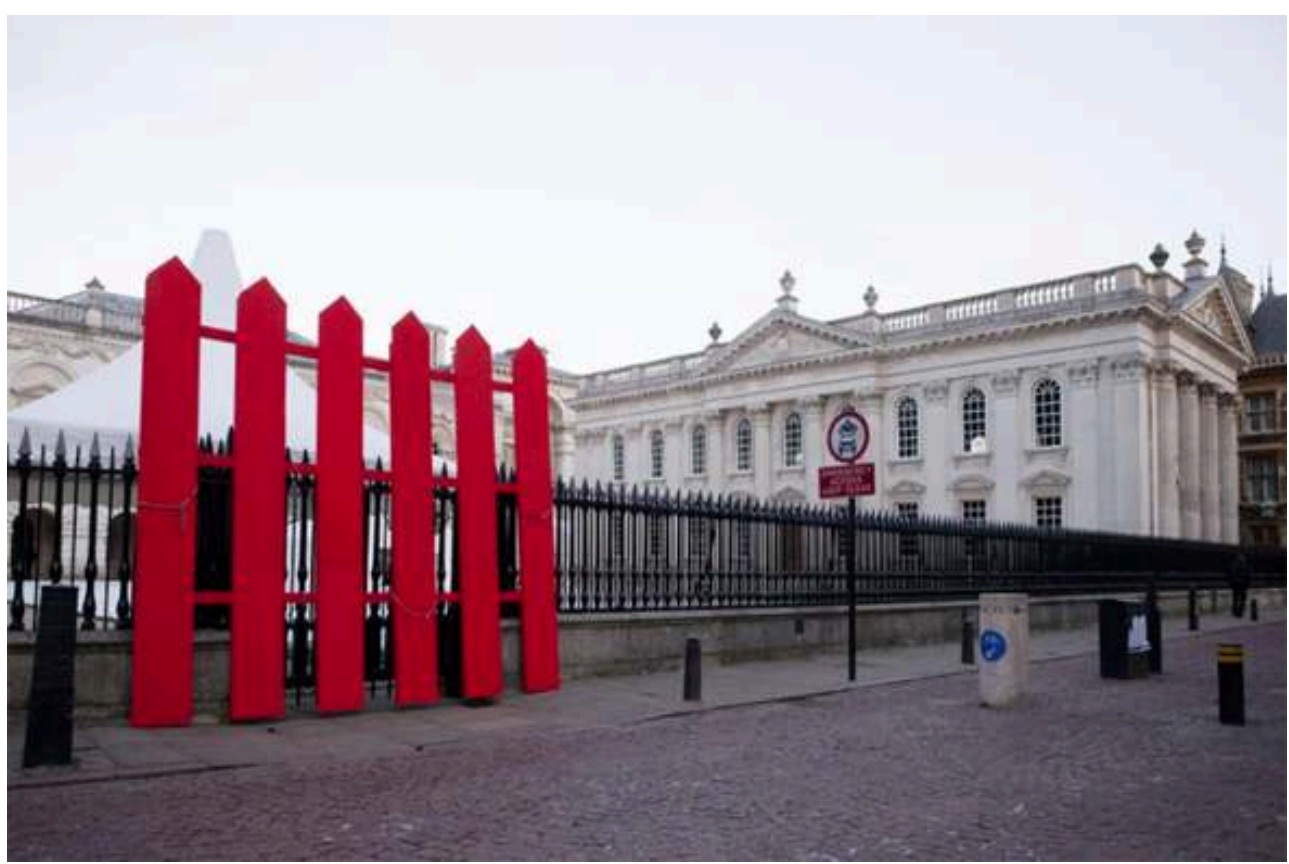

Source: https://discoversociety.org/2018/03/01/rethinking-collective-action-the-2018-universitystrike/.

UCU branches across the sector reported an extraordinary rise in membership applications (UCU February 2018) and staff queued on picket lines to join the union in order to take industrial action. In effect these staff were choosing to take industrial action and lose 14 days' pay, with the prospect of further action in order to defend their pensions and challenge the ideological, neoliberal university. Moreover, it is estimated that membership of UCU increased by almost 10,000:

In the three months to 28 February 2018, UCU had an additional 9059 members, $7752 \mathrm{HE}$ and $1304 \mathrm{FE} . .$. These figures are in $\mathrm{HE} 349 \%$ up on the equivalent period last year and $394 \%$ on the equivalent period two years ago. (Personal communication Regional official UCU).

The rise in activism within the UCU led to a remobilisation and democratisation of the union, with new members, particularly younger members, often working on precarious, low-paid contracts, for example postgraduate researchers, taking active roles in organising picket lines and protests in their branches. A key shift in the response to a proposed settlement of the action, brokered by the Advisory Conciliation and Arbitration Service (ACAS), was a grassroots branch-led rejection culminating in a demonstration outside UCU's head office. Hundreds of strikers protested outside the UCU offices (Figures 8 and 9) to make clear their views to the General Secretary, Sally Hunt, about the perceived capitulation by UCU negotiators. UCU members told Sally Hunt - as she argued in favour of the proposed settlement - that she was "now objectively on the side of the employers". 
Figure 8. UCU members protest outside the UCU Head Office in Carlow Street London

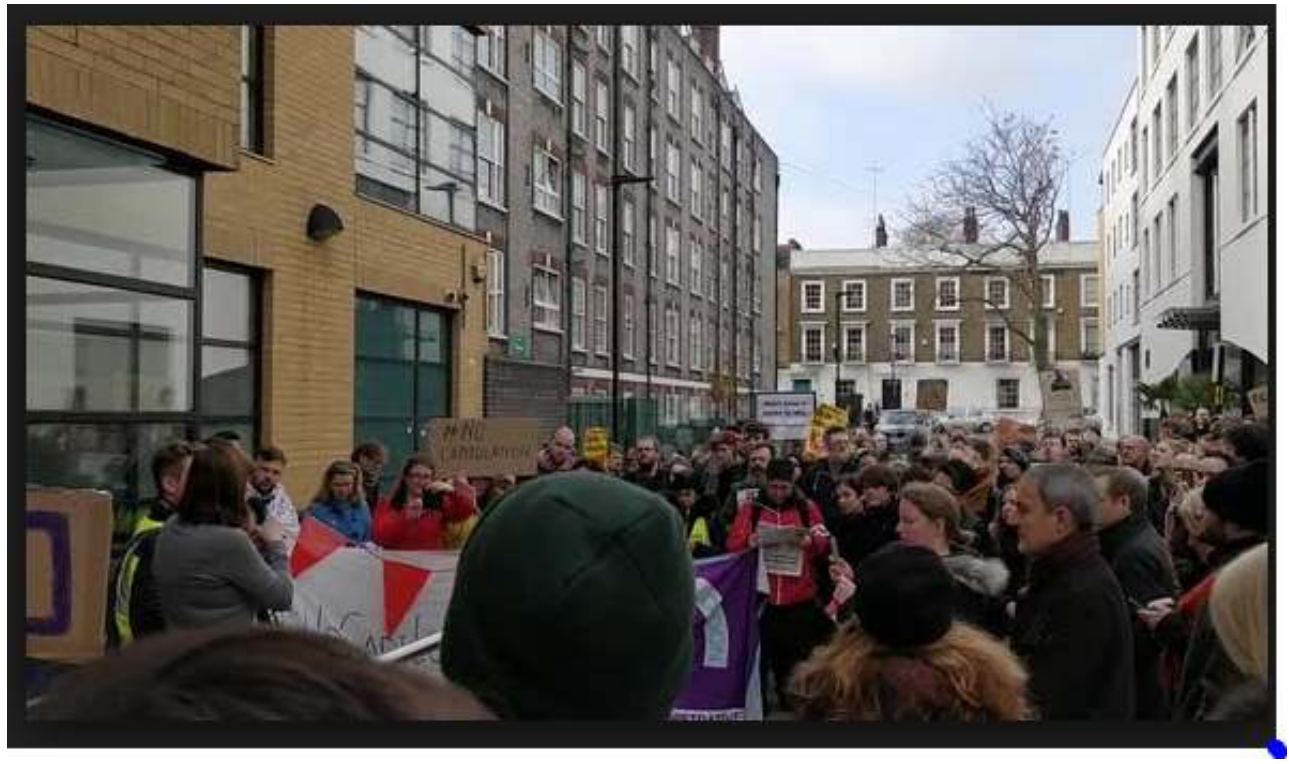

Source: Reelnews, 2018

Figure 9. UCU members protest outside the UCU Head Office in Carlow Street London.

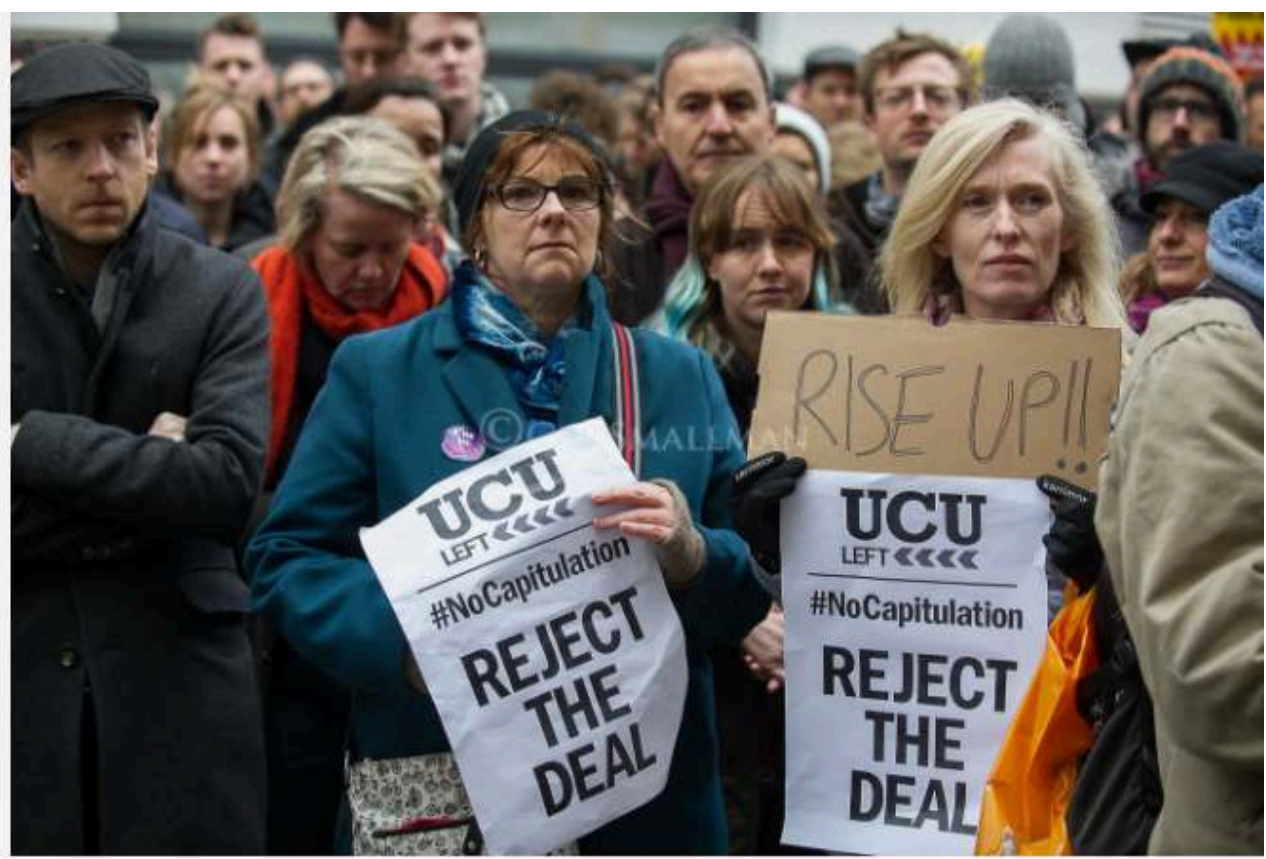

Source: Guy Smallman. 
Figure 10. UCU members protest outside the UCU Head Office in Carlow Street London

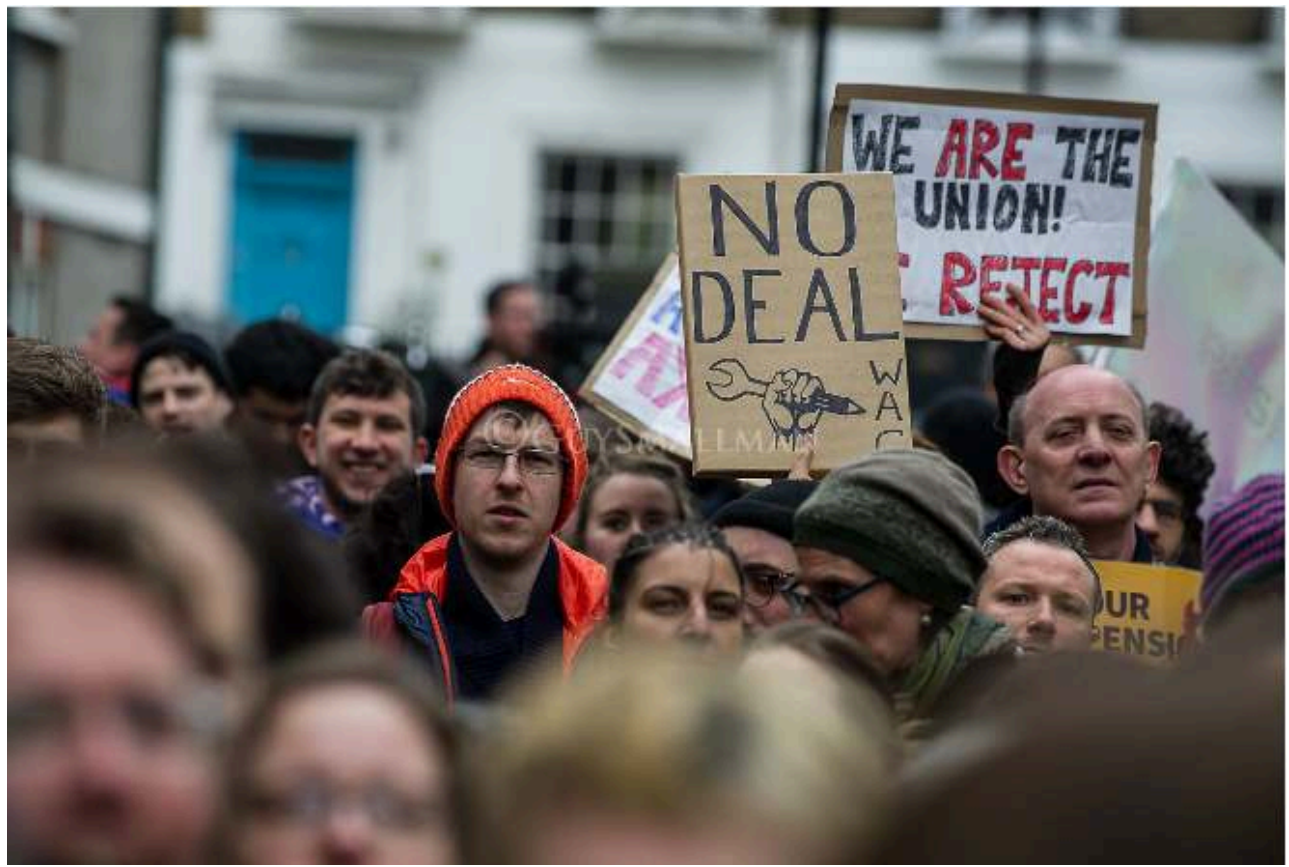

Source: Guy Smallman.

Both academics and students were using the language of protesters, e.g. "Resist" and "Rise Up" and taking direct action, for instance through occupations, signifying a change in what was previously a service union to that of a campaigning union. The radicalisation of staff and students as a consequence of the USS industrial dispute has set the foundations for future grassroots, joint organising and campaigning (Figures 11 and 12). 
Figure 11. Staff and students march through Bristol, November 16, 2018

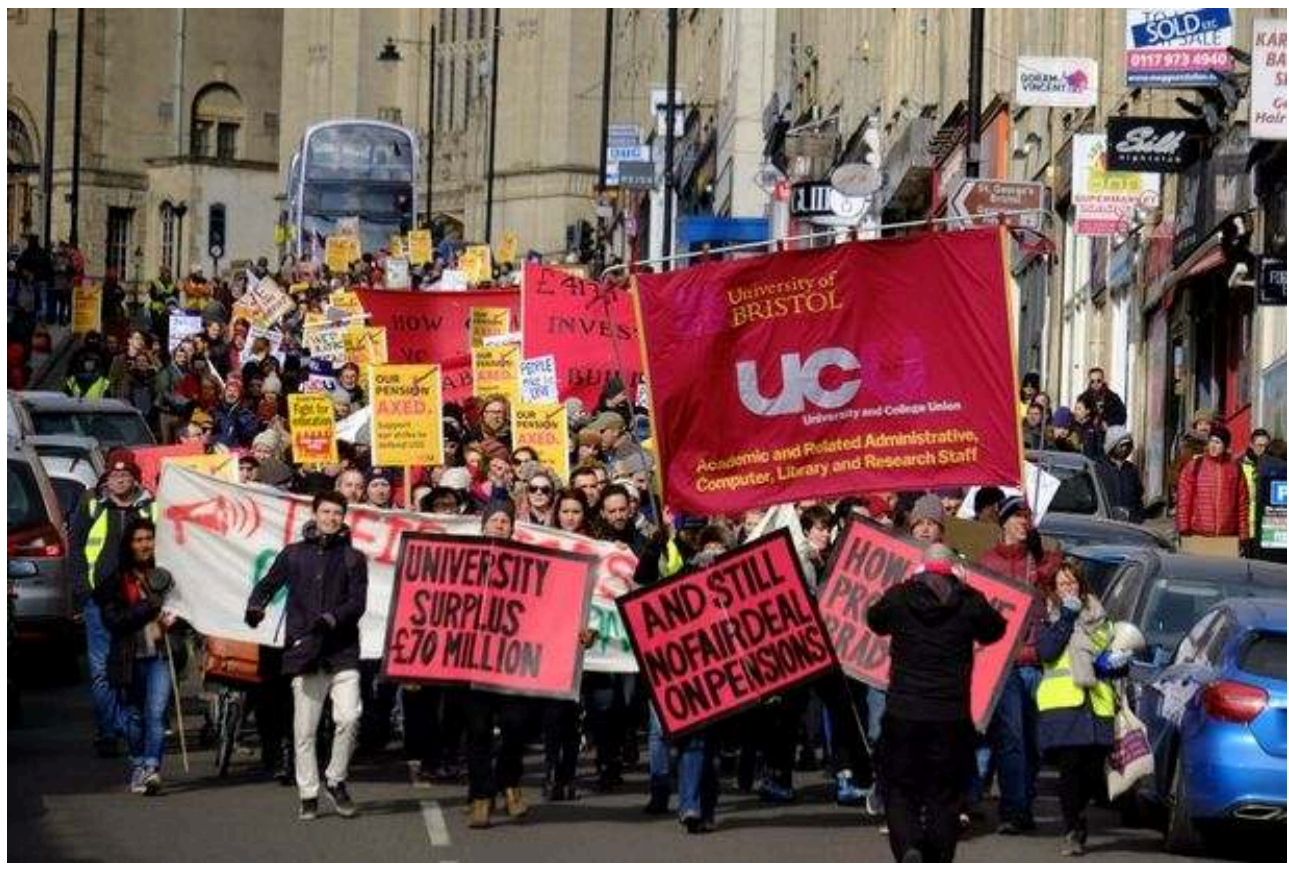

Source: Bristol Post, https://www.bristolpost.co.uk/news/bristol-news/university-bristol-lecturers-inprecarious-2225173.

Figure 12. Staff and students march through Liverpool, March 8, 2018

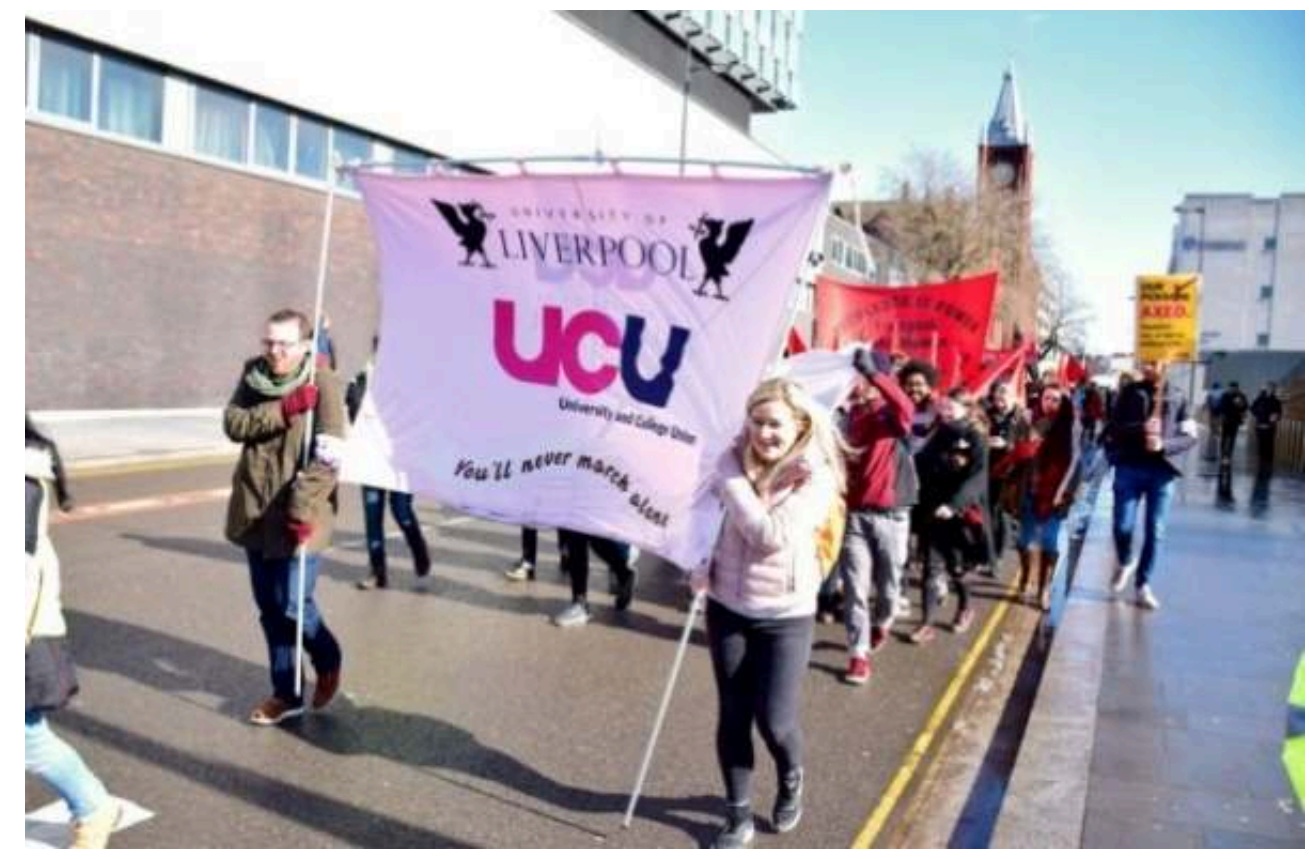

Source: Liverpool Walton Constituency Labour Party Twitter account, https://twitter.com/ Ipoolwaltonclp/status/971833984153018370. 


\section{The rise and impact of the neoliberal agenda on education}

15 As discussed above, the reaction by academics and students to recent proposed changes to the established HE pension scheme, the Universities Superannuation Scheme (USS), was unexpected and decisive, and demonstrated greater solidarity across academia than had been seen in the UK for many years (Left Foot Forward 2018). As Marsh (2018) noted in his deconstruction of the USS valuation of the scheme, which he described as a scandal, the 'de-risking' of the pension fund through the sale of the "growth assets (equities, property etc)" would significantly reduce the amount of benefits paid into future pensions. The estimated costs to universities of $£ 11 \mathrm{bn}$ over the next 20 years, as a result of increased employer contributions, would of course be met ultimately by members of the scheme. However, what was interesting about this industrial action is that it was, at the time, the most effective - and some would argue the only - way that academics and students could protest about the impact of the neoliberal agenda on HE.

As Deem et al. (2007) argue, the autonomy and judgement of public sector professionals has been eroded through the ever-increasing grip of neoliberal management, empowered by elite politicians and corporations. This is as true of HE as it is of the wider public sector. Successive UK governments have pursued a neoliberal agenda to dismantle public sector education, from primary school through to HE since at least the 1970s. An evaluation of Gillard's (2018) historical account of more than 145 reports by charities, commissions and government departments, government bills, acts and reviews regarding education in England identifies what we conceptualise as the 'DNA' to dismantle publicly funded education, whilst diverting public funds to private education. This is a classic manifestation of the hegemonic neoliberal project, as proposed by Harvey (2007), Hall $(1978,2011)$, and Hall and Massey (2010). Arguably, the DNA model sits alongside Gillard's (2018) extensive history of education in the UK, by providing an interactive snapshot of key developments in legislation that have led to the dismantling of public sector education.

One of the key highlights of the neoliberal agenda included the Conservative government's Education Act (1979) which repealed Labour's Act (1976) that had included a clause which allowed Local Education Authorities (LEAs) to retain (and fund) selective secondary schools. The same government's Education Act (1980) instituted the Assisted Places scheme, which allowed LEAs to use public money to fund places in private schools.

Notably, the Further and Higher Education Act (1992) removed Further Education (FE) and sixth-form colleges from LEA control and established Further Education Funding Councils (FEFCS), bringing all funding of HE under the control of the Higher Education Funding Councils (HEFCs), and for the first time, introduced market-like competition for funding between institutions. It was the 1997 Labour Government led by Tony Blair that opened the door to student-funded HE education, proposing in its manifesto that student maintenance costs should be borne by graduates, albeit on a means-tested basis. The Dearing report (1996) commissioned by the previous Conservative government recommended that students bear $25 \%$ of the cost of tuition, although Dearing did argue that government grants should remain in place. It is, of course, a matter of record and history that the cost of tuition was increased for students whilst almost all grants have been abolished. 
It was again a Labour government, neoliberal in its actions, which introduced $£ 1,000$ tuition fees in 1998, abolishing the $£ 1,700$ grant, replaced with student loans, which are means tested and increasingly restrictive. The Education (Student Loans) Regulations 1990 paved the way for the privatisation of student funding for HE, transferring the provision, management and collection of student loans to the private sector. Despite calls by almost 80 backbench Labour MPs to abolish tuition fees, Tony Blair's government passed the Higher Education Act (2004) and, in 2006, student fees were raised to $£ 3,000$. This eventually led to the introduction of $£ 9,250$ (a purported maximum) fees by the Conservative/Liberal Democrat coalition government in 2012. It is against this backdrop of the introduction, then rapid rise in student fees that students began to protest initially against the increase in fees, staging protests in 2011, but more recently, and as previously discussed, against neoliberal policies in HE. Further examples of the neoliberal dismantling of HE in the UK can be seen in initiatives to increase private, for-profit universities. Commenting on the announcement of the privately funded university BPP University College, owned by NASDAQ-listed American Apollo Group, Finlayson (2010) stated:

Let's be clear about what has happened. The House of Commons has not voted only for a rise in tuition fees in English universities. It has voted for the privatisation of British Higher Education.

Special mention must be reserved, however, for the successive Conservative governments of Margaret Thatcher and John Major which sealed the lid on public funding of universities, applying severe financial pressure. This was achieved through the reduction of student funding by $36 \%$ between 1989 and 1997, and linking funding to Research Assessment Exercises, thereby exerting market values on HE (Collini 2010). As Collini notes, reviewing the Browne et al. (2010) report on which these changes in funding were premised, the consequence was:

A system in which the universities are providers of services, students are the (rational) consumers of those services, and the state plays the role of the regulator. (Collini 2010)

21 It is this long-term drive towards the neoliberalisation of HE by successive UK governments that we identify as a purposeful agenda to redefine publicly funded education as a for-profit provider rather than a universal network (Meek 2015). Finlayson's (2010) question was as close as prescience gets: "Which Liberal Democrat minister will be the first to leave the cabinet in order to take up a position on the board of a private provider of Higher Education?"

In any event, it did not long take for ex-Universities Minister David Willets to take advantage of the neoliberal policies he stewarded, taking a job as 'education investment advisor' for a development company with the purpose of recruiting universities to an east London campus. As Holmwood (2017) commented, HERA 2017:

[...] completes a process of the privatization of higher education in England that began with the Browne Report in 2010 and subsequent Government White Papers and legislative changes to remove direct public funding of undergraduate programmes in humanities and social sciences and to replace it with student fees supported by loans.

The dismantling of HE in the UK is an agenda inextricably bound in neoliberal ideology. 


\section{The DNA of the neoliberal agenda in HE}

the dismantling of the HE sector. The 3D, interactive model (in development) will allow users to click on text in a visual representation, which would then link the reader to an original source: corresponding links would take the reader to publications, explanations and discussions of the effect of the act on government or policy. It is anticipated that this model would be a useful contribution to research into the neoliberal agenda. Not only does it vividly represent the ways in which publicly-funded education, in particular in England, has been dismantled, it allows researchers ready access to information adding to understandings of the ongoing debate around neoliberalism in HE. The development of the model is represented in 2D form in Figure 13. 
Figure 13. Development of the model in 2D form

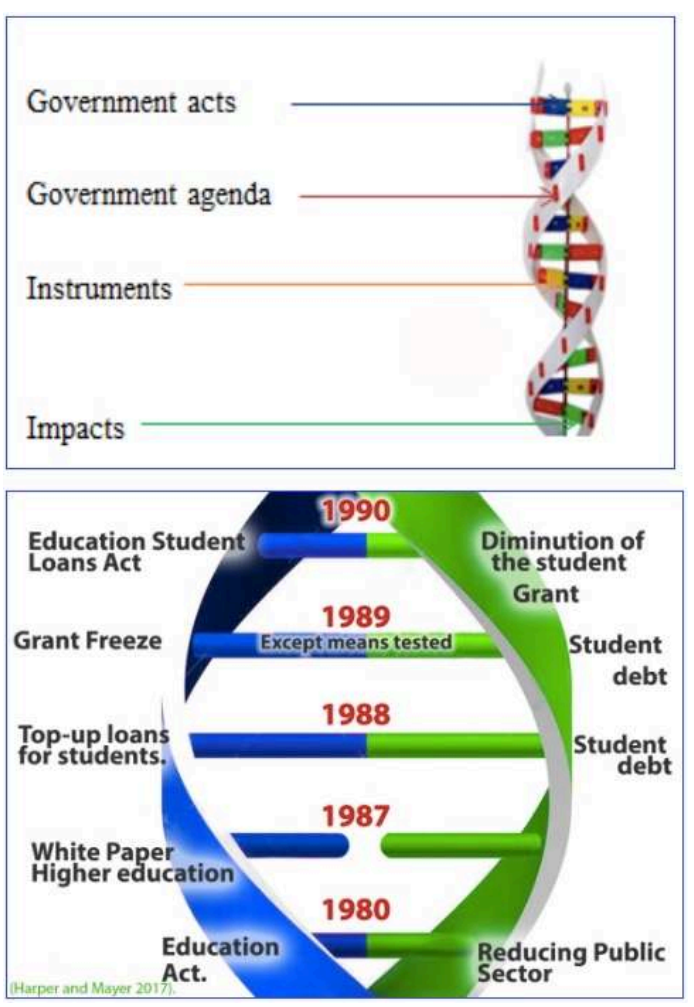

Source: Marian Meyer and Sue Eccles, 2017.

28 In parallel, government Acts over a similar period of time led to conditions whereby many primary and secondary schools were "acadamised", as were Further Education colleges, resulting in an increasingly privatised education system. For the most part, these academies are run for profit by large corporate entities, some of which have been sponsored by wealthy individuals and religious groups. In some cases, so-called "Free Schools" have been established, whereby LEAs are required to fund schools set up by parents, supported by charities such as the New Schools Network, which to date has had questionable outcomes, according to a recent Times Higher Education report (Hazell 2018).

Interestingly, the notion that universally accessible education was originally conceived in order to provide a workforce for the capitalist industrial economy, in some sense, supports the link between industry and education, however such notions were superseded by Humanist and later Democratic concepts of education (Rustin 2016). The dismantling of public sector education has returned to the concept of HE as a "trainer" of workforces, rather than democratically-organised places of learning and the creation of knowledge - as seen in the earlier discussion regarding MK:U.

\section{The current landscape}

Understanding the DNA of the neoliberal agenda in HE also helps us understand the current and most recent developments across the UK HE sector. HERA 2017 radically changed HE in the UK; its effects could have been the final nail in the coffin of publicsector education, significantly impacting research activities and academic freedom. 
Private for-profit companies will be accredited to use university titles, award degrees, charge high fees, operate without student unions and academic freedom, and able to close "unprofitable" programmes with no liabilities. Academic freedom, once a cornerstone of university endeavours, will now be driven by market demands, and consequently, scholarly independence and the freedom to engage in the critical pursuit of knowledge will be significantly limited. As Woodhouse (2009) presciently noted, academic excellence is incompatible with the requirements of those seeking to commercialise education for private profit, whether it be business partners or the HE sector. Brennan and David (2010: 6) argue that:

In their focus on skills and employability, policy makers may be underselling the importance of universities to the creation and maintenance of a stable and fair social order.

The UK Teaching Excellence Framework (TEF) will further commodify HE, leading to a greater consumerist approach to HE. Indeed, the stated premise of the recentlyintroduced HE regulator, the Office for Students (OfS) which replaced the Higher Education Funding Council for England (HEFCE) and the Office for Fair Access (OFFA), is to "increase choice and competition in higher education", in effect creating a studentconsumer model of HE. The OfS, which has limited student representation on its board and significantly no member from the National Union of students (NUS), lost no time in commissioning research into "students' perceptions of value for money" (OfS 2018). The OfS employs the language of markets and consumers, clearly positioning the regulator as a key component of the neoliberal higher education sector.

We are facing the ultimate marketisation of education, including the introduction of 2year degrees, and reduction in student choice as "unprofitable" programmes are closed (Hall 2016). Whilst there are major challenges - imposed by education policy-makers impacting negatively on the student experience, these could be addressed by rethinking the purposes of universities. Collini (2017) contends that the "idea of the university" has been the subject of repetitive, inconclusive debate and discourse for more than 150 years. If we accept that universities should play an important and significant role in society, perhaps we must redefine what that role should be.

University staff and student unions have an important role to play in the defence of publicly-funded and publicly-owned HE. It is important to note that the Labour Party manifesto (2017: 47) includes a pledge to establish a Ministry of Labour, committing a Labour government to "repeal the Trade Union Act and [to] roll out sectoral collective bargaining". The manifesto also promises a radical restructuring of HE financing, including re-establishing student grants and abolishing fees. It is within this context that we believe it is possible to reimagine and reclaim Higher Education.

As part of the effort to rethink the purpose of HE, we argue that it is essential that the authoritarian neoliberal agenda pursued by successive UK governments be widely exposed, challenged and resisted (Bowen et al. 2014; Bruff and Tansel 2018). McGettigan $(2013,2015)$ argues that the rapid expansion and increasing marketisation of the sector is a core function of a neoliberal economic policy, arguing however that it is possible to challenge this ideology. It is possible to build on the work of Morley (2016), Holmwood, Hickey and Wallis (2016), Freedman and Bailey (2011) and others to challenge and resist the neoliberal agenda in education, and expose increasing socio-economic inequalities. Neoliberal HE policies can be challenged through evidence-based research: as extant research argues, the UK HE sector can be re-invigorated and knowledge production 
pursued as a site of transformation and radical, emancipatory, transformative education and learning (Mezirow 1978a, b; 2000, Nind 2014).

The call to reclaim universities is not new. Wright and Greenwood (2017) posit the threat of the possibility of "external" forces or management buyouts, citing a report commissioned by the employers' body Universities UK (Stanfield 2009), which

provided vice-chancellors with models that would enable the university to maintain its degree-awarding powers and its charitable (beneficial tax) status, whilst transferring the university's assets to a new company where the managers had an interest, could raise capital on the stock exchange, and as one of the diagrams boldly states, "strip profit".

Wright and Greenwood (2017: 46) argue that there is a danger that senior managers of universities have begun to think of themselves as "stewards of their own enterprise as de facto owners". Indeed, post-92 universities are "corporations", with the benefit of charitable status - the best of both worlds for Chief Executive Officers of these institutions - and Russell Group Vice-Chancellors have taken to styling themselves as Chief Executives and even as Presidents for the American "market" (Shaw 2013).

Although the proposition that higher education is a wider societal economic good has been posited by successive governments, such benefits are a contested contention. For example, scholars including Alvesson (2013: 78) have argued that

[...] there is no easy way to establish a causal relationship between increased investment in higher education and economic growth [...].

Nevertheless, the notion that upward social mobility is a positive outcome of $\mathrm{HE}$ education - as espoused through government policy - suggests that through widening access and greater inclusivity, all of society may benefit (Cabinet Office 2010; Department for Business, Innovation and Skills, OFFA and HEFCE 2014; Department for Business, Innovation and Skills 2015).

The intensification of neoliberalisation in society goes hand-in-hand with the economics of the HE sector and cannot be ignored as they are so closely aligned with the Higher Education sector (Canaan 2013; Springer et al. 2016 cited by Asher 2017). The claims made by successive governments about the impact of universities on the UK economy include the surprising comment by the then Universities and Science Minister David Willetts "that universities continue to be counter-cyclical, defying the recession". Willetts's statement supports the contention that the HE sector is viewed by governments through the neoliberal prism of commodification and marketisation (Department for Business, Innovation and Skills and Willetts 2015). Kalfa et al.'s study (2017) identified that, whilst many academics are ideologically opposed to managerialism, in other words to authoritarian neoliberalism, compliance and selfprotection pervades the HE sector. In order to rationalise the constraints within which many academics labour, cynicism, disengagement, cognitive dissonance and avoidance are increasingly commonplace. Kalfa et al. (2017) contended that academics 'game' the world of academia, using Bourdieu's metaphor, although they acknowledge that there are pockets of resistance, although these tend to seek to protect the individuals' own well-being. However, Kalfa et al.'s study (2017) predates the USS pension dispute, with contributed to shifting the mood amongst academics, academic-related staff, postgraduate students and indeed the wider student body. 


\section{Challenging the current landscape} has emboldened UCU members who are increasingly angry at the attack on their pensions and $19 \%$ reduction in pay over the last decade. In autumn 2018, members of education unions were balloting on industrial action over a pay and equality claim to include:

An increase to all spine points on the 50 -point national pay scale of $7.5 \%$ or $£ 1,500$ whichever is greater;

$£ 10$ per hour minimum wage with all HEIs to become foundation living wage employers ensuring all campus staff are paid at least the foundation living wage rate. 
45

Should the ballot be successful in meeting the government threshold for industrial action, that is $50 \%$ turnout with the majority voting to take industrial action, the unions would begin sustained strike action until their claim is settled.

Our call to action would be that academics form an international, inclusive, emancipatory, democratic collaborative project aimed at exposing and challenging the privatisation of HE in the Anglophone world. This can be achieved through the publication of a manifesto to dismantle the neoliberal HE sector, creating an HE sector that serves the intellectual needs of society, abjuring the demands of business and industry (Boyle 2017). This collaboration should include, although not be limited to, student-led research projects such as the UK Student Movement Research Project, The Convention for Higher Education, social activists and journalists, in order that research be widely disseminated though open, accessible democratic channels. To answer Collini (2012), this is what universities are for.

\section{The Manifesto}

We acknowledge the existence of previous manifestoes. However, building on the recent resurgence in student activism in partnership with university staff, this manifesto is intended to encourage and empower collectives and unions including staff and students, to organise and lobby for the purpose of reclaiming our university education sector. We base our manifesto on extant manifestoes published by collectives including Aberdeen University (Reclaiming our University 2017), Democratise Sussex (Staff and Students Collective 2018) and Goldsmith UCU Gold paper (2016) in response the government Green Paper on Higher Education (Hubble 2015).

Teach-ins organised by striking staff and supporting students have also led to movements working to reclaim or create educational spaces, such as "communities of discovery" as proposed by Coffield and Williamson (2012), and cooperative universities (Cook 2013, Melrose 2018). It is this growing movement rejecting the neoliberal agenda that our manifesto seeks to address. As Morley (2016) urges, in reimagining the university we must:

Resist being co-opted by narrow policy agendas [...] challenge and expose increasing socio-economic inequalities/exclusions [and] re-invigorate knowledge production as a site of transformation/possibility.

The manifesto does not speak to philosophical debates around HE. Rather, its aim is to offer a template for collectives seeking to reclaim their University. The establishment of University Community Cooperatives, as democratically-controlled sites for university staff to jointly act and have a voice as part of a wider publicly funded universal network, is an essential feature of democratic society. The aim of the manifesto is to add to calls by collectives seeking to reclaim their universities. It also, in part, speaks to previous discourse on the need to reclaim universities in the UK. Adopting what they argue is a pragmatic approach, Levin and Greenwood (2016) propose Trust, Cooperative and employee-led universities. Hall (2016) calls for revolutionising the way in which academics engage with universities through "affirmative disruption" of the "microentrepreneurs of our own selves and lives [academics] have become" in order to survive in the "current capitalist economic system". He urges the affirmative disruption of the disruptors, that is to say global corporations, that have disrupted publicly-funded higher education as exampled by 
Apollo/Vistria Group's BPP University College Ltd. As previously discussed, Morley (2016), Holmwood, Hickey and Wallis (2016), Freedman and Bailey (2011) have argued for the re-imagining and reclaiming of the UK university.

The University Community Cooperative: A manifesto and core principles for the operation and governance of Higher Education institutions in England and Wales

We argue that establishment of University Community Cooperatives, as part of a wider publicly-funded universal network, is an essential feature of democratic, civic society. This manifesto is intended to add to and inform the extant wider debate about the purpose and function of universities. Critique of, and contributions to this debate, are keenly welcome.

1. All universities will cease to function as corporate entities led by Executives, governed by unelected Boards and Councils.

2. An urgent review of university governance will establish a set of agreed core principles and agreements through which the University Community Cooperative will function. This review shall be undertaken by unions representing all university staff and students, together with government departments responsible for education.

3. We call for cessation of market-driven competition in higher education. Education is neither a product nor an offering, it has a civic purpose and is an important human endeavour, adding to the sum of the body of knowledge so as to enhance civic societies and individuals.

4. We call for the repurposing of universities in England and Wales, and the establishment of communities of learning and discovery, which value equally the study of and research into Science Technology and Medicine, The Arts, The Humanities and Social Sciences disciplines.

5. University Community Cooperatives will organise and operate as environmentally and educationally sustainable entities.

6. The University Community Cooperative will comprise all staff and students, who shall be equally valued and respected.

7. The University Community Cooperative will publish and widely disseminate an ethical statement, detailing the ways in which inclusivity and equality will be enshrined in the governance of the university, together with accessible information about their contributions to the collaboration creation of knowledge and understandings of the human experience for the benefit of all.

8. The University Community Cooperative will publish transparent financial information to include the salaries and remuneration of all staff.

9. The University Community Cooperative will end outsourcing, including academic, professional, support and caretaking and catering staff. This is in recognition that all members of the University Community Cooperative are integral to its functioning and success.

10. The University Community Cooperative shall and must be a place of academic and personal freedom to explore and exchange ideas and debates: a space in which academic freedom of speech is enshrined and protected.

11. Wisdom, tolerance, truth and freedom of expression will be privileged in the University Community Cooperative.

12. The University Community Cooperative abjures the managerialist neoliberal language of industry and commerce, and will become communities of practice rather than places of line management, employer and employee. Staff will not be subject to the neoliberal exigencies of the "Human Resource" model of organisational structure and systems.

13. Such policies and procedures that are agreed by the University Cooperative Community will be proposed, composed and negotiated by elected representatives of the community, comprising: academics, students, professional staff, support staff, and where relevant members of the local community. 
14. Distinctions between the educator and the student are outdated and antithetical to the notion of co-created knowledge. Members of the University Community Cooperative well function collaboratively in collegiality.

15. Research and education will be undertaken in accordance with the prevailing needs of society rather than external commissioners of research and knowledge exchange seeking to modify and commercialise generated knowledge.

16. University Community Cooperative systems will function for the benefit of the community rather than perform for the benefit of corporatised systems. To this end the classroom, the office, the lecture theatre, the virtual learning environment and the University estate will be designed to meet and fit the purposes defined by the community.

17. The University Community Cooperative Estate will include diligentlymaintained, affordable student accommodation. This to be managed by a collective to include $25 \%$ of elected student representatives, for the benefit of students, and not for profit.

18. Systems of control will be removed, surveillance of staff and students will be removed, and trust will be extended to all members of the community in order to engender collegiality and cooperation.

19. Research and education will be premised on deep and thoughtful creative and critical thinking and reflection. The lifelong pursuit of learning and nurturing of knowledge will be a fundamental principle of university communities.

20. A truly democratic society cannot function without an educated and empowered citizenry. Research and education will be done so as to educate citizens so that they may take their place in a democratic and civic society.

21. Rejecting colonialist notions of UK university education, university communities will actively seek to recruit, engage and exchange knowledge and understanding with scholars, academics and students from across the world. No cost will be associated with these endeavours as the benefits will outweigh financial considerations.

\section{Finance}

22. We reject the current neoliberal University-funding model, calling for fundamental reform of the funding of universities and study.

23. The University Community Cooperative will be publicly funded through taxation, and absent of vested interests. To that end University Community Cooperatives will function as charities, rather than businesses or corporations.

24. All University Community Cooperative staff will be paid according to sectorial pay negotiations with government; students will receive grants to the equivalent of a living wage.

25. The University Community Cooperative will not employ staff on casualised or zero-hours contracts.

26. The University Community Cooperative will not employ professional or support staff on contracts any less favourable than academic contracts.

The University Space

27. The University Community Cooperative will be used as a public space for the benefit of all, forming part of a publicly-funded universal network existing for the benefit of citizens.

28. The University Community Cooperative will seek to engage with and serve the needs of the local community, including schools and other universal networks.

29. University Community Cooperative libraries, lecture theatres and other places of learning and knowledge co-creation will be shared spaces, open and accessible to all.

30. Rigorous debate and freedom of speech will be equally protected.

31. General assemblies will be called for the purpose of discursive discussion and debate within the University Community Cooperative, and act as a forum to inform its governance. 
32. Crèches will be available on a non-profit basis for members of the University Community Cooperative.

33. The University Community Cooperative Estate will incorporate places to rest, eat, and take time to ponder and reflect.

Education and Research

34.Collaborative knowledge production through rigorous and evidenced academic endeavours, including research, will be premised on the principles of radical and emancipatory transformative teaching and learning. Students will be encouraged to make mischief and challenge orthodoxies. Students will be encouraged to take risks, to learn from failures as well as successes, and to reflect on that learning.

35. Curricula and modes of assessment will be collectively and collaboratively agreed by scholars and students.

36. The University Community Cooperative will agree to review and revise its academic footprint and pedagogy, embedding in education and research the means to challenge discrimination and exclusion in all its forms. Political and socioeconomic orthodoxies will be questioned, challenged and debated, encouraging critical analysis and thinking, and freedom of thought and expression.

37. The University Community Cooperative will not act in compliance with the REF, TEF, OfS, including the NSS, or any other mechanism or regulator which does not align with this manifesto.

38. Teaching materials will not be commodified or marketed for profit, rather they will be available as open access sources for the benefit of all.

39. Intellectual Property of staff and students will be used for the benefit and enrichment of the University Community Cooperative.

40. All formal teaching and research will cease during term recess in order that members of the University Community Cooperative may take time to reflect on term time work, and to pursue extracurricular interests so as to enrich their work/ life balance. Term recesses will allow members of the local and wider community to access and use the University Community Cooperative space for individual, group or collective community purposes, including self-determined education, sport, the arts and entertainment.

As previously discussed, the UCU pensions dispute has seen an unprecedented rise in activism by both students and staff in the UK Higher Education landscape. The increase in UCU membership with the arrival of some 5,000 University staff, which included early-career academics, casualised staff, and staff on zero-hours contracts, the "precariat," has radically altered the union. The genie is out of the bottle, and whatever the outcome of the dispute, students have occupied university spaces, and staff and students have challenged the hegemony of UUK, regulation of universities, and the governing bodies of pre-92 universities. It is possible, through the efforts of individuals, collectives, unions and all citizens concerned with and in HE, to work together to achieve truly inclusive, democratic, communities of learning. These communities will reclaim universities, organise, and act for the benefit of civic society. We have seen staff and student unions come together in common cause to challenge the neoliberal university model, those same staff and students have the power to dismantle the neoliberal agenda: to disrupt the disruptors. This manifesto seeks to contribute to the struggle to reject neoliberal realism and reclaim our universities. The challenge facing reformers of UK HE is considerable, although less insurmountable than envisioned a few short months ago. 


\section{BIBLIOGRAPHY}

Alvesson, Mats. The Triumph of Emptiness: Consumption, higher education and work organisation. Oxford: Oxford UP, 2013.

Asher, Gordon. "Practicing What We Preach? Writing and Publishing in, Against and Beyond the Neoliberal University." In Richard Hall and Joss Winn (ed.). Mass Intellectuality and Democratic Leadership in Higher Education. London: Bloomsbury Academic, 2017: 199-259.

Asserson Law Offices. “Have You Missed Out On Teaching Time This Term?” 2018 https:// www.universitycompensation.co.uk/

BBC. "Students occupy Glasgow uni room in pension row." BBC News, 15 March 2018. http:// www.bbc.co.uk/news/uk-scotland-glasgow-west-43413006

Belfield, Chris, Jack Britton, Lorraine Dearden and Laura van der Erve. "Higher Education funding in England: past, present and options for the future." London: Institute for Fiscal Studies, 2017. https://www.ifs.org.uk/publications/9334

Bowen, William M., Michael Schwartz and Lisa Camp. End of Academic Freedom: The Coming Obliteration of the Core Purpose of the University. Charlotte, NC: Information Age Publishing, 2014.

Boyd, Catherine. "A beginner's guide to the Office for Student." Wonkhe, 2018: https:// wonkhe.com/blogs/a-beginners-guide-to-the-office-for-students/

Boyle, Paul. "How should universities respond when academic freedom is under threat?" Times Higher Education, 13 May 2017.

Brennan, John and Miriam David. "Teaching, learning and the student experience in UK higher education." In John Brennan et al. Higher Education and Society: a research report. London: The Open University, Centre for Higher Education Research and Information, 2010: 5-12.

Bruff, Ian and Cemal Burak Tansel. "Authoritarian neoliberalism: trajectories of knowledge production and praxis," Globalizations 16 (3) 2019: 233-244. DOI: 10.1080/14747731.2018.1502497

Cabinet Office. The Coalition: our programme for government: Freedom Fairness Responsibility. London: HM Government, 2010.

Callard, Felicity, Deepa Govindarajan Driver, Jo Grady, Nick Hardy, Jaya John John, Claire Marris, and Leon Rocha. "The JEP report has vindicated the UCU strike, but where next for the USS dispute?." Number 52: \#USSbriefs52, 2018. https://medium.com/ussbriefs/the-jep-report-hasvindicated-the-ucu-strike-but-where-next-for-the-uss-dispute-951632af94da

Coffield, Frank and Bill Williamson. From Exam Factories to Communities of Discovery: The Democratic Route. London: UCL Institute of Education Press, 2012.

Cork, Tristan. "Live: Bristol student sit-in of University bosses' offices enters third day." Bristol News, 7 March 2018. https://www.bristolpost.co.uk/news/bristol-news/live-bristol-studentsoccupy-university-1297803

Collini, Stefan. “Browne’s Gamble.” London Review of Books 32 (21) 2010: 23-25.

Collini, Stefan. What are Universities for? London: Penguin, 2012.

Collini, Stefan. Speaking of Universities. London: Verso Books, 2017.

Competition and Markets Authority. "Higher education Undergraduate students: your rights under consumer law.” 2015 https://assets.publishing.service.gov.uk/government/uploads/ 
system/uploads/attachment_data/file/415732/Undergraduate_students_-

_your_rights_under_consumer_law.pdf

Cook, Dan. Realising the Co-operative University. A consultancy report for The Co-operative College. 2013 http://josswinn.org/wp-content/uploads/2013/12/realising-the-co-operative-universityfor-disemmination.pdf

Dearing, Ron. "The Dearing report: Review of Qualifications for 16-19 Year Olds. Summary Report." 1996. https://files.eric.ed.gov/fulltext/ED403388.pdf

Deem, Rosemary, Sam Hillyard and Mike Reed. Knowledge, higher education and the new managerialism. The changing management of UK universities. Oxford: Oxford UP, 2007.

Department for Business, Innovation and Skills and David Willetts. Contribution of UK universities to national and local economic growth. London: Department for Business, Innovation and Skills, 2015.

Department for Business, Innovation and Skills, OFFA and HEFCE. National strategy for access and student success in higher education. London: Department for Business, Innovation and Skills, 2014.

Dunn, John and Mary Anne Clark. "Life Music: The Sonification of Proteins." 2004. https:// www.leonardo.info/isast/articles/lifemusic.html

Finlayson, Alan. Britain, greet the age of privatised Higher Education. Open Democracy, 2010. https:// www.opendemocracy.net/ourkingdom/alan-finlayson/britain-greet-age-of-privatised-highereducation

Fook, Jan. "Higher Education: What Is It Good For?" Leadership Foundation for Higher Education, 2017. https://www.lfhe.ac.uk/download.cfm/docid/13B16654-2FB3-4176-8C19BC5B0F766978

Freedman, Des and Michael Bailey. The Assault on Universities: A Manifesto for Resistance. London: Pluto Press, 2011.

Gillard, Derek. "Education in England: the history of our schools." 2011. http:// www.educationengland.org.uk/index.html Goldsmiths UCU. “The Gold Paper”. 2016. https://goldsmithsucu.wordpress.com/the-gold-paper/ Levin, Morten and Davydd J. Greenwood. Creating a new public university and reviving democracy: action research in higher education. Oxford, New York: Berghahn, 2016.

Gunn, Andrew. "Most graduates will never pay off their student loans." The Conversation, 2017. https://theconversation.com/most-graduates-will-never-pay-off-their-student-loans-80582

Hubble, Sue. "Higher Education Green Paper: Fulfilling our potential." House of Commons Library, 2015. http://researchbriefings.files.parliament.uk/documents/CBP-7399/CBP-7399.pdf

Left Foot Forward, "Biggest student protest in 5 years: hundreds occupy universities over staff pension strike." Left Foot Forward, 6 March 2018. https://leftfootforward.org/2018/03/biggeststudent-protests-in-5-years-hundreds-of-occupy-universities-over-staff-pension-strikes/

Hall, Stuart. Policing the Crisis. London: Macmillan, 1978.

Hall, Stuart. “The Neo-Liberal Revolution.” Cultural Studies 25 (6) 2011: 705-28. DOI: 10.1080/09502386.2011.619886

Hall, Stuart and Doreen Massey. "Interpreting the crisis." Soundings (44) 2010. https:// www.lwbooks.co.uk/soundings/44/interpreting-crisis

Hall, Gary. The Uberfication of the University. Minnesota: U. of Minnesota P., 2016.

Harvey, David. A Brief History of Neoliberalism. Oxford: Oxford UP, 2007. 
Hazell, Will. "Exclusive: Fate of Toby Young free schools charity to be revealed in next month." Times Higher Education, 28 February 2018. https://www.tes.com/news/exclusive-fate-toby-youngfree-schools-charity-be-revealed-next-month

Heale, James. "Students occupy top floor of Senate House for university pension strikes." The Tab, 5 March 2018. https://thetab.com/uk/bristol/2018/03/05/students-occupy-top-floor-of-senatehouse-for-university-pension-strikes-32758

Holborow, Marnie. "Language, ideology and neoliberalism." Journal of Language and Politics 6(1) 2007: 51-73. DOI: 10.1075/jlp.6.1.05hol

Holmwood, John, Tom Hickey, Rachel Cohen and Sean Wallis. The Alternative White Paper for Higher Education: Knowledge for a Successful Society. London: The Convention for Higher Education, 2016.

Holmwood, John. "Requiem for the public university." Discover Society, 2 May 2017. https:// discoversociety.org/2017/05/02/requiem-for-the-public-university/

Kalfa, Senia, Adrian Wilkinson and Paul J. Gollan. "The Academic Game: Compliance and Resistance in Universities.” Work, Employment and Society 32(2) 2017: 274-291. DOI: $10.1177 / 0950017017695043$

Labour Party. "The Labour Party manifesto: for the many not the few". 2017. https:// labour.org.uk/wp-content/uploads/2017/10/labour-manifesto-2017.pdf

Logan, Caitlin. "Occupied: Glasgow students show solidarity with striking lecturers." Common Space, 15 March 2018. https://www.commonspace.scot/articles/12519/occupied-glasgowstudents-show-solidarity-striking-lecturers

McGettigan, Andrew. The Great University Gamble: Money, Markets and the future of Higher Education. London: Pluto Press, 2013.

McGettigan, Andrew. PERC Paper 6 - The Treasury View of Higher Education. London: Goldsmiths University of London, 2015.

Melrose, Jamie. “Towards a Radical Infrastructure: Counter-Reforming Higher Education.” Novaramedia, 2018. http://novaramedia.com/2018/02/18/a-radical-infrastructure-counterreforming-he/

Meek, James. Private Island: Why Britain Now Belongs To Someone Else. London: Verso, 2015.

Mezirow, Jack. Education for Perspective Transformation: Women's re-entry programs in community colleges. New York: Columbia University, 1978a.

Mezirow, Jack. "Perspective transformation”. Adult Education (28) 1978b: 100-110. DOI: $10.1177 / 074171367802800202$

Mezirow, Jack. Learning as Transformation: Critical Perspectives on a Theory in Progress. San Francisco: Jossey Bass, 2000.

Morley, Louise. “Future Directions for UK Higher Education”. University of Sussex: Centre for Higher Education and Equity Research (CHEER), 2016.

Morgan, John, "Higher Education and Research Bill passed by UK parliament." Times Higher Education, 27 April 2017. https://www.timeshighereducation.com/news/higher-education-andresearch-bill-passed-uk-parliament

Mortimer, Caroline. "Graduate loses bid to sue Oxford University over failure to get a first." The Independent, 8 February 2018. https://www.independent.co.uk/news/education/education-news/ oxford-university-sue-fail-first-degree-high-court-faiz-siddiqui-brasenose-college-a8199921.html 
Nind, Melanie. What is inclusive research? London, New York: Bloomsbury, 2014.

Owens, John. "UCU general secretary heckled by strikers while giving pensions deal statement." News flare, 13 March 2018. https://www.newsflare.com/video/189397/health-education/ucugeneral-secretary-heckled-by-strikers-while-giving-pensions-deal-statement

Northern Ireland Public Service Alliance. Public Sector Pensions. Myths \& Facts. Belfast: NIPSA, 2011. https://nipsa.org.uk/publications/Myths-and-Facts-web.pdf

Reel News. "UCU pensions dispute energised by strikes, protests and occupations." Reel news, 21 March 2018. https://reelnews.co.uk/2018/03/21/all-reelnews-campaigns/workplace-struggles/ ucu-pensions-dispute-energised-by-strikes-protests-and-occupations/

Roller, Matthew. “Oxford academics launch 'blockchain university”. Cherwell, 22 March 2018. http://cherwell.org/2018/03/22/oxford-academics-launch-blockchain-university/

Rustin, Michael. "The neoliberal university and its alternatives." Soundings (63) 2016: 147-170. https://www.lwbooks.co.uk/soundings/63/the-neoliberal-university

Ryals, Lynette. "Milton Keynes 'will redefine the civic university for the 21st century'." Times Higher Education, 30 March 2018. https://www.timeshighereducation.com/blog/milton-keyneswill-redefine-civic-university-21st-century

Schwarz, Bill. "Editorial: The scandal of contemporary universities." Soundings (69) 2018: 1 -14. DOI: 10.3898/SOUN:69.editorial.2018

Shaw, Claire. "Goodbye vice-chancellor, hello chief executive. Do changes to university job titles matter and what do they say about the role of our institutions and their leaders?" The Guardian, 16 April 2013. https://www.theguardian.com/education/2013/apr/16/higher-education-jobtitles

Stanfied, Glynne. Developing Future University Structures: New Funding and Legal Models. London: Universities UK, 2009.

Students Loans Company. "Student Loans company.” 2018. https://www.slc.co.uk/

UCU. "Poll shows students support pension strikes and blame universities for the disruption." UCU, 22 February 2018. https://www.ucu.org.uk/article/9345/Poll-shows-students-supportpension-strikes-and-blame-universities-for-the-disruption

UCU. "Universities face 14 days of strikes during exams if pension dispute not resolved." UCU, 8 March 2018. https://www.ucu.org.uk/article/9392/Universities-face-14-days-of-strikes-duringexams-if-pension-dispute-not-resolved?list=1676

Woodhouse, Howard. Selling Out: Academic Freedom and the Corporate Market. Montreal, CA: MQUP, 2009.

\section{ABSTRACTS}

This article is a response to the introduction of the Higher Education and Research Act (HERA) 2017, which in effect opens the door to privatised, deregulated Higher Education (HE) across the UK. The Act allows private for-profit companies, from their inception, to use the university title (previous legislation required a waiting period of four years), award degrees, and charge unregulated fees: they will not be required to establish or fund student unions. This is, we argue, the neoliberal project in action. As publicly-funded universities in the UK struggle to meet politically-driven imperatives such as the Research Excellence Framework, the Teaching 
Excellence Framework, audits, metrics and other performance indicators, new for-profit funded universities are emerging which position themselves as meeting industry and student expectations, rather than as centres for the creation, dissemination and research of knowledge. The only challenges to the hegemony of Universities UK (UUK), regulation of universities, and the governing bodies of pre-92 universities have come from individual academics and students, via UCU industrial action in defence of academic staff pensions. Strikes in 61 UK universities in 2018 were widely seen as a watershed in HE activism. Against this backdrop, an ideologicallydriven, neoliberal agenda has begun to dismantle publicly-funded HE in England and Wales. To demonstrate this, we develop an interactive model predicated on the DNA double helix, where we illustrate links between government Acts and regulations and the concomitant dismantling of public sector education. Based on the review of over 140 government instruments, we argue the model represents the backbone of the neoliberal project which is intended to privatise all areas of education in the UK. To challenge this neoliberal agenda, we propose a manifesto to reclaim HE in England and Wales. Whilst in part the manifesto is based on the premise that a Labour government will be elected within the next 5 years, this is not a prerequisite for reclaiming our universities. The manifesto seeks to establish University Community Cooperatives - collegiate, collaborative spaces of knowledge creation. Our analysis of the current political landscape in England and Wales, in light of recent activism within HE, leads us to be optimistic. We argue that it is possible, through the efforts of individuals, collectives, unions and all citizens concerned with, and in, HE to work together to achieve truly inclusive, democratic, communities of learning. These communities will reclaim universities, organise, and act for the benefit of civic society. Staff and student unions have come together in common cause to challenge the neoliberal university model, rendering them the power to dismantle the neoliberal agenda; our manifesto seeks to contribute to the struggle to reject neoliberal realism and reclaim our universities.

Cet article constitue une réponse au vote par le Parlement britannique du Higher Education and Research Act (HERA) en 2017, qui a pour effet de d'ouvrir la voie à un enseignement supérieur privatisé et dérégulé au Royaume-Uni. Cette loi permet à des entreprises privées à but lucratif, dès leur création, d'utiliser le titre d'université (là où elles devaient jusqu'ici attendre quatre années pour le faire), de délivrer des diplômes et de demander des droits d'inscription en dehors de tout cadre réglementaire. Elles n'ont aucune obligation de créer ou de financer des syndicats étudiants. Selon nous, il s'agit ici d'une mise en œuvre du projet néolibéral. Alors que les universités publiques du Royaume-Uni peinent à atteindre les objectifs qui leur sont fixés par le gouvernement à travers le Research Excellence Framework, le Teaching Excellence Framework ou d'autres indicateurs de performance, de nouvelles universités à but lucratif émergent, qui se positionnent comme apportant des réponses aux attentes des entreprises et des étudiants, et non comme des centres pour la création, la dissémination et la recherche du savoir. Les seules oppositions à l'hégémonie de l'organisation patronale Universities UK (UUK) et aux directions des universités sont venues d'initiatives individuelles d'universitaires et d'étudiants qui se sont engagés dans le mouvement de grève lancé par le syndicat UCU pour défendre les retraites des universitaires. Les grèves qui ont eu lieu dans 61 universités au Royaume-Uni au printemps 2018 ont été généralement perçues comme marquant une inflexion dans le militantisme dans l'enseignement supérieur. C'est sur un tel arrière-plan qu'un programme néolibéral, au contenu idéologiquement marqué, s'emploie à démanteler l'enseignement supérieur public en Angleterre et au Pays de Galles. Pour en apporter la démonstration, nous proposons un modèle interactif reprenant la double hélice de l'ADN, qui permet d'illustrer les liens entre action législative et réglementaire gouvernementale, d'une part, et démantèlement concomitant de l'éducation publique, de l'autre. Ce modèle permet de représenter la structure du projet néolibéral, dont nous pouvons affirmer, après examen de plus de 140 mesures mises en œuvre par les 
gouvernements successifs, qu'il vise à privatiser l'ensemble du secteur de l'éducation au Royaume-Uni. Pour résister à ce programme néolibéral, nous proposons un manifeste visant à la réappropriation de l'enseignement supérieur en Angleterre et au Pays de Galles. Même si ce manifeste repose en partie sur l'hypothèse d'un retour au pouvoir des travaillistes dans les 5 prochaines années, ce n'est pas une condition nécessaire à la réappropriation de nos universités. Ce manifeste envisage la création d'universités coopératives - ou coopératives des communautés universitaires - c'est-à-dire des espaces collégiaux et coopératifs de création du savoir. Notre analyse du paysage politique actuel en Angleterre et au Pays de Galles, menée à la lumière du militantisme qui s'est fait jour dans l'enseignement supérieur, nous permet d'être optimistes. Nous affirmons qu'il est possible, en unissant les forces des individus, des collectifs, des syndicats et de l'ensemble des citoyens concernés par l'enseignement supérieur, d'œuvrer à la création de communautés d'enseignement véritablement inclusives et démocratiques. De telles communautés se réapproprieront les universités, s'organiseront collectivement et agiront pour le bien commun. Les syndicats de personnel et d'étudiants ont fait cause commune pour résister au modèle de l'université néolibérale, se donnant ainsi les forces de démanteler le programme néolibéral. Notre manifeste constitue un apport à cette lutte visant à rejeter la raison néolibérale et à se réapproprier nos universités.

\section{INDEX}

Keywords: manifesto, neoliberalism, university community cooperatives, university, higher education, United Kingdom

Mots-clés: manifeste, néolibéralisme, coopérative de la communauté universitaire, université, enseignement supérieur, Royaume-Uni

\section{AUTHORS}

\section{MARIAN MAYER}

Marian Mayer is a Senior Lecturer in Learning Development at Bournemouth University. She is currently completing a doctoral study, 'Is transformative learning possible in a neoliberal context within higher education in the UK' which, rather than focusing on the 'process' of transformative learning, explores 'what' is transformed, and how that transformative experience occurs. Her study develops transformational learning theory and considers the potential for Bourdieu's concept of Habitus and Illeris's Identity theory to be utilised as a theoretical and methodological tool to study the impact of transformational learning on undergraduate students. Contact: mmayer[at]bournemouth.ac.uk

\section{SUE ECCLES}

Dr Sue Eccles is Acting Deputy Head of the Centre for Excellence in Learning at Bournemouth University and has worked in HE since 1995. Her research is focused around the experiences of students as they transition into, through and out of Higher Education, the Widening Participation policy agenda and how this impacts on/influences practice, and the experiences of academics particularly in relation to effective leadership practice. She has experience of strategic management and leadership, as well as in-depth knowledge and understanding of education practice within HE. Contact: seccles[at]bournemouth.ac.uk 